\title{
KOMPOSISI DAN KELIMPAHAN BIVALVIA DI EKOSISTEM LAMUN PERAIRAN JUANGA KABUPATEN PULAU MOROTAI PROVINSI MALUKU UTARA
}

\section{ANALYSIS OF COMPOSITION AND BIVALVIA INDIVIDUAL ABUNDANCE AT SEAGRASS ECOSYSTEM IN WATER OF JUANGA VILLAGE, MOROTAI ISLAND}

\author{
Djainudin Alwi' ${ }^{1}$ Iswandi Wahab ${ }^{1}$, Ilham Bisi ${ }^{1}$ \\ ${ }^{1}$ Program Studi Teknologi Hasil Perikanan, Fakultas Perikanan dan Ilmu Kelautan \\ Universitas Pasifik Morotai, Maluku Utara, Indonesia \\ Korespondensi : iswandi.fpik@gmail.com
}

\begin{abstract}
ABSTRAK
Secara ekologi bivalvia berperan dalam menjaga poduktifitas lingkungan. Kurangnya informasi mengenai keberadaan dan komposisi spesies dari Bivalvia tersebut, mendorong untuk dilakukan penelitian ini. Tujuan penelitian adalah untuk menganalisis komposisi dan kelimpahan spesies Bivalvia di ekosistem Lamun Desa Juanga Kecamatan Morotai Selatan, Kabupaten Pulau Morotai. Pengambilan sampel menggunakan metode kuadrant ukuran 1 x 1 meter untuk Bivalvia Epifauna, dan pipa paralon dengan diameter $10 \mathrm{~cm}$ untuk Bivalvia yang terdapat dalam dasar perairan (infauna). Analisis data menggunakan rumus komposisi, dan kelimpahan menggunakan rumus kelimmpahan dengan menggunakan pendekatan Excel. Hasil penelitian didapatkan sebanyak 7 spesies bivalvia yang tersebar di empat stasiun penelitian yaitu Anadara gubernculum, Donax trunculus, Dosinia dilecta, Frogum unedo, Latona cuenata, Atrina pectinata dan Ostrea lurida dengan jumlah total sebanyak 112 individu. Jumlah individu spesies bivalvia berkisar 47- 96 dengan nilai tertinggi pada adalah Anadara gubernculum pada stasiun II (96\%), dan terendah di stasiun I (47\%). Kesimpulan diperoleh (1) Komposisi spesies Bivalvia memiliki presentasi (absolut) yaitu Anadara gubernculum 0,74 sedangkan untuk spesies lain secara keseluruhan memiliki komposisi kategori (rendah) dengan nilai dibawah 0,23. (2) Kelimpahan individu dan kelimpahan relatif disemua stasiun yang memiliki nilai tertinggi yaitu jenis Anadara gubernculum.
\end{abstract}

\section{Kata kunci : Komposisi, Kelimpahan, Bivalia dan Desa Juanga}

\section{ABSTRACT}

Ecologically bivalves play a role in maintaining environmental productivity. The lack of information regarding the existence and composition of species from Bivalvia, encourages this research. The purpose of this study was to analyze the composition and abundance of Bivalvia species in the Lamun ecosystem of Juanga Village, South Morotai District, Morotai Island Regency. Sampling using a 1 x 1 meter quadrant method for Bivalvia Epifauna, and paralon pipes with a diameter of $10 \mathrm{~cm}$ for Bivalvia found in the bottom of the water (infauna). Data analysis using composition formula, and abundance using Excel approach. The results obtained as many as 7 species of bivalves scattered in four research stations namely Anadara gubernculum, Donax trunculus, Dosinia dilecta, Frogum unedo, Latona cuenata, Atrina pectinata and Ostrea lurida with a total of 112 individuals. The number of individual bivalve species ranged from 47 to 96 with the highest value being Anadara gubernculum at station II (96\%), and the lowest at station I (47\%). Conclusions obtained (1) The composition of species from Bivalvia has a (absolute) presentation of Anadara gubernculum 0.74 while for other species as a whole has a (low) category composition with a value below 0.23. (2) Individual abundance and relative abundance in all stations that have the highest value are Anadara gubernculum types.

Keywords : composition, abundance, bivalves and juanga villages 


\section{PENDAHULUAN}

Ekosistem pesisir, termasuk didalamnya ekosistem lamun merupakan sistem ekologi yang unik dan spesifik, memerlukan pengelolaan yang spesifik sehingga dapat memberi manfaat bagi masyarakat. Padang lamun merupakan ekosistem laut yang penting dan mampu menyediakan makanan, habitat, dan daerah asuhan bagi beberapa spesies, kerang, dan penyu laut. Ekosistem lamun adalah satu dari tiga ekosistem utama wilayah pesisir dan mempunyai fungsi sosial-ekologis yang bermanfaat bagi manusia, dan salah biota laut yang berada di padang lamun adalah Kelas Bivalvia (Wahyudin et al, 2016).

Bivalvia merupakan salah satu kelas dalam Filum Moluska yang memiliki dua cangkang yang setangkup sering disebut dengan kekerangan. Padang Lamun dan Bivalvia memiliki keterkaitan sesamanya, salah satu diantaranya adalah memiliki karakteristik tipe substrat yang sama yang dijadikan sebagai habitat bagi Bivalvia. Selain itu asosiasi bivalvia dengan lamun, memiliki keterkaitan yang kuat dalam siklus makanan. Sehingga menpengaruhi komposisi dan keberadaan dari bivalvia. Menurut Wahab et al, 2018, tekanan dan perubahan lingkungan dapat mempengaruhi jumlah jenis dan perbedaan pada struktur komunitas makrozoobentos. Serasah yang terdapat di Padang Lamun akan mengendap didasar perairan, kemudian diuraikan oleh mikroorganisme yang menjadi makanan Bivalvia. Hasil penguraian yang dilakukan oleh mikroorganisme dapat menjadi sumber makanan bagi larva ikan-ikan kecil dan menjadi makanan bagi biota lain (Hermala et al, 2015).

Secara ekonomi Bivalvia dapat dimanfaatkan sebagai bahan pangan yang bergizi bagi masyarakat pesisir, dan sumber ekonomi yang tinggi karena cangkangnya dapat dimanfaatkan sebagai hiasan yang mahal (Septiana 2017). Sejalan dengan itu Putri, (2005) dalam Yusran (2014) menyatakan bahwa Bivalvia merupakan salah satu dari lima anggota dari Filum Moluska yang memilik nilai ekonomis, dan Bivalvia (Pelecypoda) terdiri dari clams, mussels, oyster dan scallops.

Perairan laut di wilayah Pulau Morotai memiliki, keanekaragaman biota dan ekosistem yang terdiri dari ekosistem mangrove, terumbu karang dan ekosistem lamun. Ekosistem lamun tersebesar hampir di seluruh wilayah Pulau Morotai, salah satunya di wilayah perairan Desa Juanga Kecamatan Morotai Selatan, Kabupaten Pulau Morotai. 
Perairan Ekosistem Lamun Desa Juanga yang berada di Kecamatan Morotai Selatan Kabupaten Pulau Morotai, merupakan salah satu perairan yang memiliki berbagai macam sumber daya hayati laut. Salah satu dari sumberdaya hayati tersebut adalah spesies dari Kelas Bivalvia (kekerangan), sebagai penghuni kawasan ekosistem lamun di kawasan tersebut. Kurangnya informasi tentang keberadaan dan komposisi spesies dari Kelas Bivalvia ini, mendorong penulis untuk melakukan penelitian ini. Tujuan penelitian ini adalah (1) untuk menganalisis komposisi spesies dari Bivalvia, dan (2) mengkaji kelimpahan individu dan kelimpahan relatif Bivalvia di Ekosistem Lamun kawasan Desa Juanga Kecamatan Morotai Selatan, Kabupaten Pulau Morotai Provinsi Maluku Utara.

\title{
METODE PENELITIAN
}

Penelitian ini dilaksanakan pada Bulan Desembar 2019, yang berlokasi di Ekosistem Lamun Perairan Desa Juanga, Kecamatan Morotai Selatan Kabupaten Pulau Morotai, Provinsi Maluku Utara. Lokasi penelitian dapat dilihat pada Gambar 1.

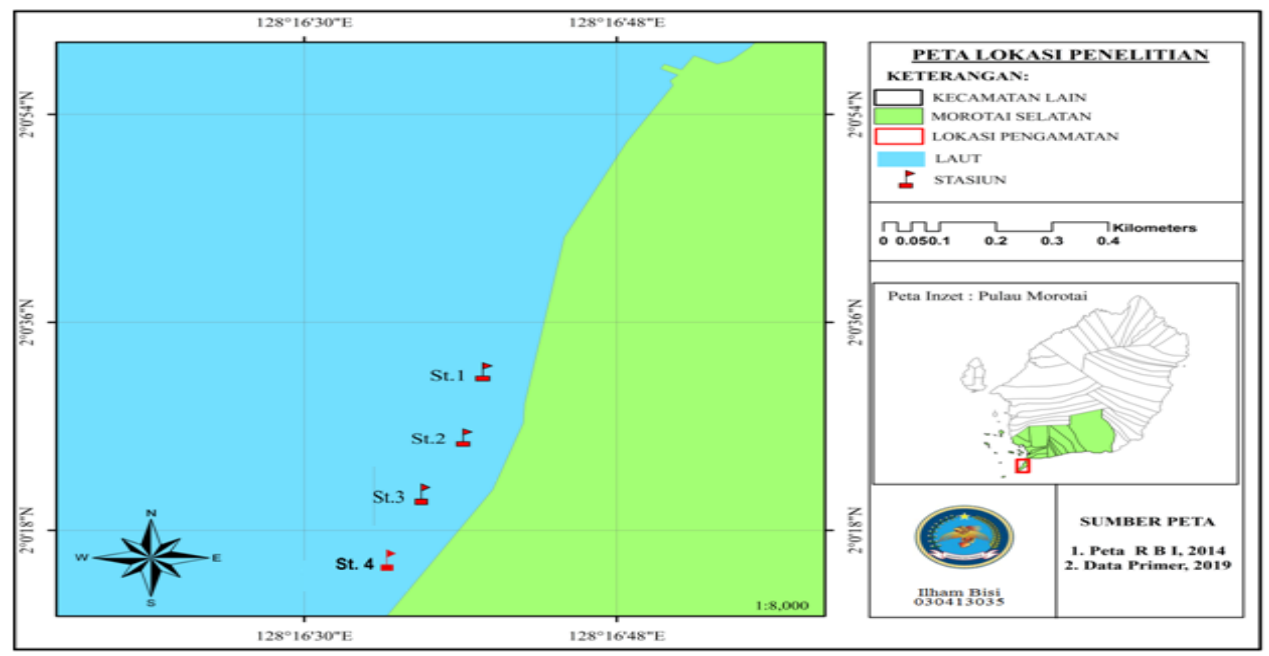

Gambar 1. Lokasi Pengambilan sampel

\begin{abstract}
Alat dan Bahan
Alat dan bahan yang digunakan dalam penelitian ini diantaranya adalah kuadrat berukuran $1 \mathrm{~m} \times 1 \mathrm{~m}$, meteran roll, GPS, plastik sampel, kamera, alat tulis, thermometer, handrefraktometer, kertas lakmus, ayakan bertingkat, pipa corr, buku identifikasi dan spesies dari Bivalvia sebagai sampel.
\end{abstract}




\section{Teknik Pengambilan Data}

Teknik pengambilan data dengan melakukan survei awal untuk mengamati objek, dan kondisi karakteristik lingkungan untuk menentukan stasiun penelitian. Penentuan stasiun penelitian berdasarkan keberadaan dan sebaran Bivalvia pada Ekosistem Lamun sebagai habitat hidupnya. Pengambilan sampel Bivalvia permukaan dasar perairan menggunakan metode transek kuadrant ukuran 1 meter $\mathrm{x} 1$ meter untuk Bivalvia epifauna permukaan dasar perairan (English et al, 1997), dan pipa paralon diameter 10 $\mathrm{cm}$ yang digunakan untuk mengambil sampel Bivalvia infauna. Penarikan transek dengan rol meter sepanjang 50 meter ke arah laut, dimulai dari awal sampai ditemukan objek batas terluar objek yang dikaji. Terdapat 3 transek di masing-masing stasiun dengan jarak penempatan antara kuadrant 10 meter, dimulai dari 0-50 meter. Total pengulangan pada masing-masing stasiun 12 kali. Pengambilan sampel dari kawasan penelitian mencakup kegiatan observasi, identifikasi, komposisi spesies, analisis kelimpahan individu dan kelimpahan relatif dari Bivalvia. Sedangkan untuk pengambilan data parameter lingkungan dilakukan secara in-situ dilokasi penelitian pada masing-masing stasiun, yang terdiri dari suhu, salinitas dan $\mathrm{pH}$. Berikut sketsa pengambilan sampel dilapangan dapat dilihat pada (Gambar 2).

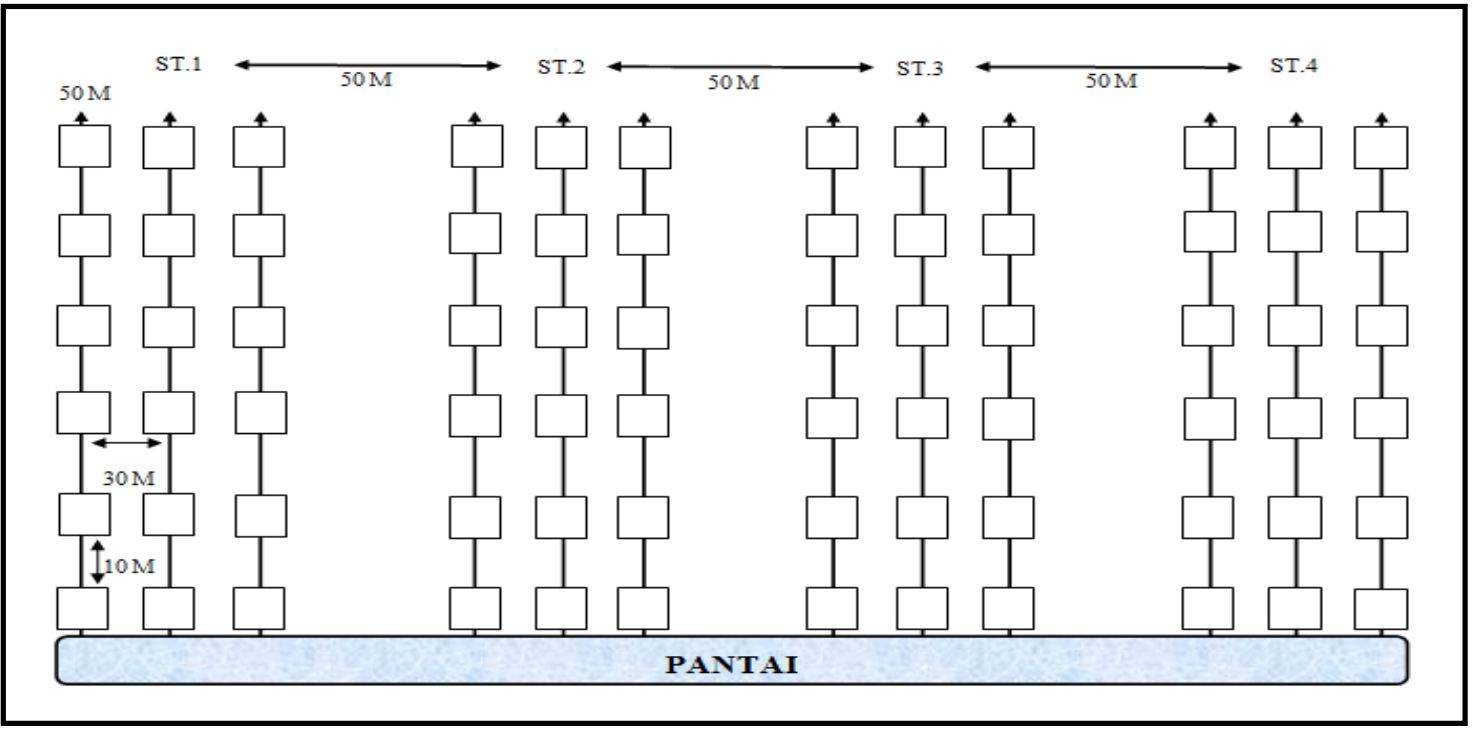

Gambar 2. Sketsa Pengambilan data lapangan

Sumber : Data primer 2019 


\section{Pengambilan Bivalvia Pada Ekosistem Lamun}

Pengambilan sampel bivalvia kawasan Ekosistem Lamun, dilakukan pada masingmasing kuadrant (ukuran 1meter x 1meter) dengan mengambil sampel yang mengendap pada permukaan substrat perairan, dasar substrat dan yang menempel di lamun. Sebelum diambil, sampel yang ditemukan diidentifikasi berdasarkan panduan Setiawan (2010) dan Patrick dan Ameson (1995). Sampel dihitung kelimpahan spesies dan kelimpahan individu, kemudian sampel dimasukan kedalam plastik sampel yang telah diberi label untuk dilakukan identifikasi lanjut di laboratorium.

\section{Analisis Data}

Data yang diperoleh kemudian ditabulasi kedalam Microsoft Excel, diolah dan ditampilkan dalam bentuk tabel dan grafik.

\section{Kelimpahan Individu}

Formula dalam menghitung kelimpahan individu mengacu pada (Brower dan Zar, 1998).

Dimana:

$$
\mathrm{D}=\mathrm{ni} / \mathrm{A}
$$

D : Kelimpahan individu spesies ke-i (ind $/ \mathrm{m}^{2}$ )

ni : Jumlah individu spesies ke-i (individu)

A : Luas quadrant (m)

\section{Kelimpahan Relatif}

Formula dalam menghitung kelimpahan relatif mengacu pada (Cox 1967, dalam Effendy 1993) sebagai berikut:

$$
\mathrm{KR}=\underline{\mathrm{n} / \mathrm{A}} \times 100 \%
$$

Dimana :

$$
\begin{aligned}
& \mathrm{KR}=\text { Kelimpahan Relatif }(\%) \\
& \mathrm{ni}=\text { Jumlah individu perjenis bivalvia } \\
& \mathrm{N}=\text { Jumlah Total Individu bivalvia }
\end{aligned}
$$




\section{Komposisi Spesies dari Bivalvia}

Analisis komposisi spesies dari Bivalvia, dianalisis dengan rumus Komposisi yang modivikasi sebagai berikut.

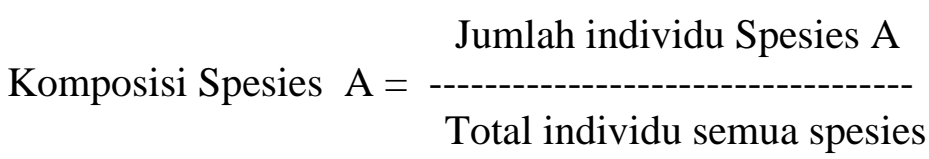

Ketentuan: Jika $\mathrm{K}=0,75-1,0$ berarti kehadiran absolut

$$
\mathrm{K}=0,50-0,75 \text { berarti komposisi sedang }
$$$$
\mathrm{K}<0,25 \text { berarti komposisi rendah. }
$$

$$
\text { Komposisi Stasiun }=\frac{\text { Kehadiran di Stasiun A }}{\text { Kehadiran Total Stasiun }}
$$

Ketentuan: Jika $\mathrm{K}=$ 0,75-1,0 berarti kehadiran absolut

$$
\mathrm{K}=0,50-0,75 \text { berarti komposisi sedang }
$$

$\mathrm{K}<0,25$ berarti komposisi rendah.

\section{HASIL DAN PEMBAHASAN}

\section{Komposisi Jenis Bivalvia}

Komposisi spesies Bivalvia yang ditemukan di lokasi penelitian terdiri dari 7 famili yaitu, Donacidae, Veneridae, Cardiidae, Sididae, Pinnidae dan Ostreidae, dan yang paling banyak ditemukan adalah Famili Arcidae dengan komposisi spesies terbanyak adalah Anadara gubernaculum. Komposisi spesies Bivalvia yang ditemukan di perairan Ekosistem Lamun Desa Juanga Kecamatan Morotai Selatan dapat di lihat pada tabel 1.

Tabel 1. Komposisi Jenis Bivalvia Pada Perairan Desa Juanga

\begin{tabular}{llcccccc}
\hline & & \multicolumn{5}{c}{ Stasiun } & \\
\cline { 3 - 6 } \multicolumn{1}{c}{ Famili } & \multicolumn{1}{c}{ Spesies } & I & II & III & IV & Komposisi & Keterangan \\
\hline Arcidae & Anadara gubernaculums & 18 & 26 & 19 & 20 & 0,74 & Absolut \\
Donacidae & Donax trunculus & 5 & 0 & 0 & 0 & 0,04 & Rendah \\
Veneridae & Dosinia dilecta & 4 & 0 & 0 & 0 & 0,03 & Rendah \\
Cardiidae & Fragum unedo & 10 & 1 & 1 & 1 & 0,12 & Rendah
\end{tabular}




$\begin{array}{llcccccc}\text { Sididae } & \text { Latona cuneata } & 1 & 0 & 0 & 0 & 0,01 & \text { Rendah } \\ \text { Pinnidae } & \text { Atrina pectinata } & 0 & 0 & 1 & 0 & 0,01 & \text { Rendah } \\ \text { Ostreidae } & \text { Ostrea lurida } & 0 & 0 & 0 & 5 & 0,04 & \text { Rendah } \\ & \quad \text { Total } & 38 & 27 & 21 & 26 & & \end{array}$

Berdasarkan Tabel 2 diatas jumlah individu dan komposisi spesies Bivalvia yang ditemukan diperairan Desa Juanga terlihat bervariasi pada empat stasiun penelitian. Jumlah spesies individu jenis yang paling banyak terdapat pada stasiun 1 yaitu 5 jenis dengan jumlah 38 individu terdiri dari Anadara gubernaculum, Donax trunculus, Dosnia dilecta, Fragum unedo, dan Latona cuenata. Pada stasiun 2 hanya terdapat 2 jenis dengan jumlah 27 individu yaitu Anadara gubernaculum dan Fragum unedo, Untuk stasiun 3 terdapat 3 jenis dengan jumlah 21 individu, jenis Anadara gubernaculum, Fragum unedo dan Atrina pectinata. Pada stasiun 4 juga terdapat 3 jenis dengan jumlah 26 individu yaitu Anadara gubernaculum, fragum unedo dan Ostrea lurida. Bivalvia yang hidup di daerah perairan Desa Juanga walaupun hanya memiliki substrat dasar perairan yang berpasir bercampur dengan lumpur dan banyak juga daerah lamun dan alga, sehingga mendukung bivalvia dapat beradaptasi dengan lingkungan tersebut.

Komposisi spesies pada keseluruhan stasiun memiliki kategori yang sama, hanya spesies Anadara gubernaculums yang berbeda. Dimana nilai komposisi spesies Anadara gubernaculums berada pada kategori (absolut) dengan komposisi 0,74\%. Spsies Donax trunculus berada pada kategori (rendah) dengan komposisi 0,04, spesies Dosinia dilecta berada pada kategori (rendah) dengan komposisi 0,03, spesies Fragum unedo berada pada kategori (rendah) 0,12, Latona cuneata (rendah) 0,1, Atrina pectinata (rendah) 0,1, dan Ostrea lurida (rendah) 0,04. Sedangkan untuk komposisi stasion didapatkan nilai yaitu 0,03 pada stasion satu, 0,24 pada stasion dua, 0,18 pada stasion tiga dan 0,23 pada stasion empat. Menurut Wahab et al, 2019, faktor habitat dan substrat perairan diduga menjadi faktor utama terkait tingginya komposisi spesies gastropoda dan bivalvia pada suatu perairan.

Hasil analisis komposisi spesies pada keseluruhan stasiun didapatkan Anadara gubernaculums memiliki nilai pada kategori absolut dikarenakan memiliki jumlah individu dan komposisi lebih banyak dari spesies yang lain. Hal ini dikarenakan substrat dan kondisi parameter lingkungan mendukung keberadaan spesies tersebut. Menurut 
Nybakken (1992), tipe substrat berpasir memudahkan moluska untuk mendapatkan suplai nutrien dan air yang diperlukan untuk kelangsungan hidupnya. Tipe substrat berpasir juga akan memudahkan menyaring makanan yang diperlukan dibandingkan dengan tipe substrat berlumpur.

Selain kondisi perairan pantai yang demikian, parameter lingkungan sangat signifikan dalam kelangsungan hidup bivalvia. Romimohtarto dan Juwana., (2001) menyatakan bahwa ditinjau dari cara hidupnya, spesies dari Bivalvia mempunyai habitat yang berlainan walaupun mereka termasuk dalam satu suku dan hidup dalam satu ekosistem. Kerang pada umumnya hidup membenamkan dirinya dalam pasir atau pasir berlumpur dan beberapa jenis diantaranya ada yang menempel pada substrat perairan, batang dan daun lamun. Habitat kerang biasanya hidup pada substrat pasir dan menetap didasar laut dengan cara membenamkan diri di dalam pasir atau lumpur juga pada karang - karang batu.

\section{Kelimpahan Individu}

Hasil analisis kelimpahan individu dari Bivalvia yang ditemukan di lokasi penelitian cukup bervariasi. Pada stasiun I terdapat Anadara gubernaculum, merupakan spesies dengan presentase tertinggi sebesar $18,00 \mathrm{Ind} / \mathrm{m}^{2}$, Fragum unedo $10,00 \mathrm{Ind} / \mathrm{m}^{2}$ kemudian jenis Donax trunculus 5,00 Ind/ $\mathrm{m}^{2}$ Dosnia dilecta 4,00 Ind/ $/ \mathrm{m}^{2}$ Latona cuneata $1,00 \mathrm{Ind} / \mathrm{m}^{2}$ (Gambar 3).

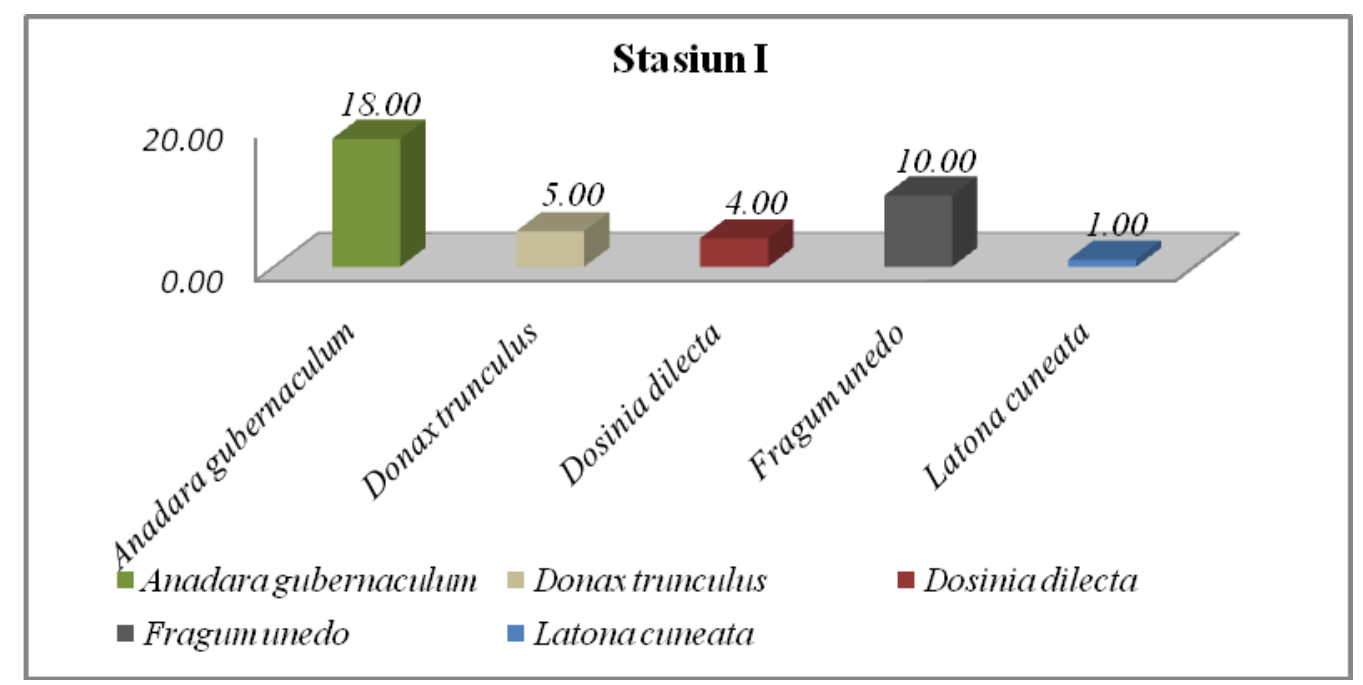

Gambar 3. Grafik kelimpahan individu bivalvia pada stasiun I. 
Pada stasiun II terlihat kelimpahan jenis yang paling tertinggi presentasinya yaitu Anadara gubernaculum sebesar $26.00 \mathrm{Ind} / \mathrm{m}^{2}$ kemudian jenis Fragum unedo sebanyak $1.00 \mathrm{Ind} / \mathrm{m}^{2}$ (Gambar 4).

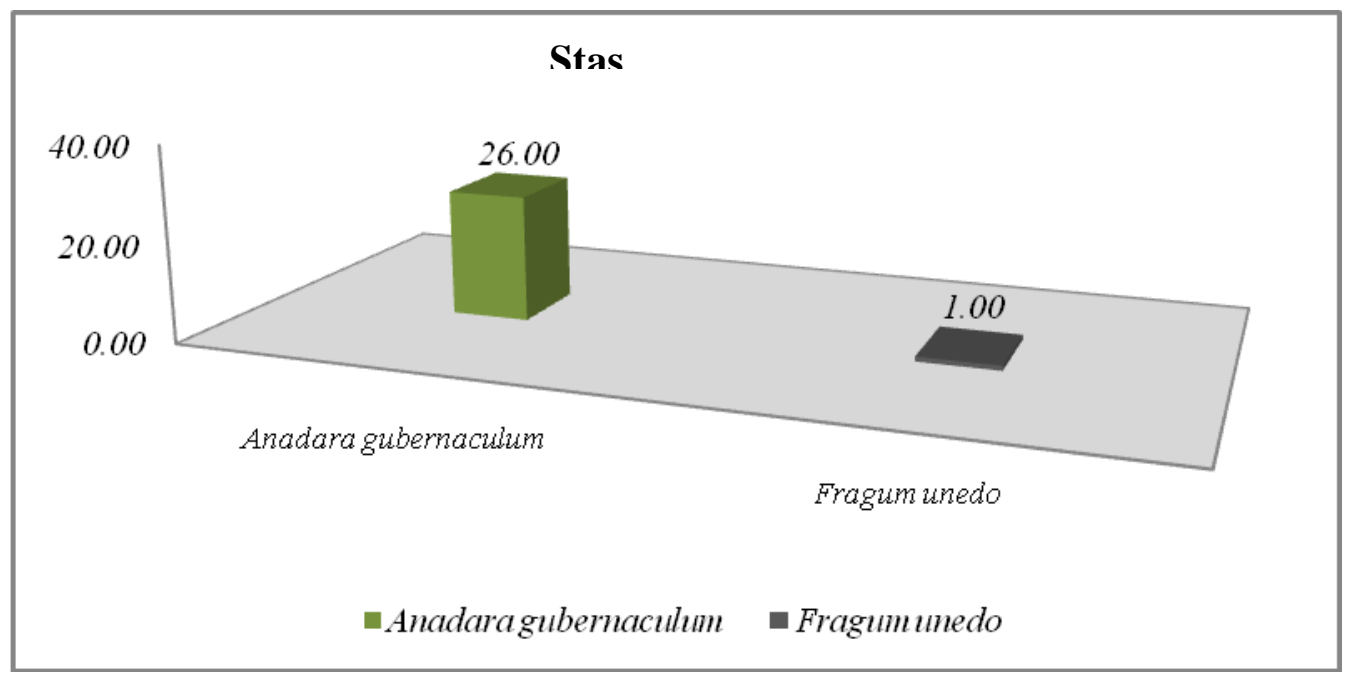

Gambar 4. Grafik kelimpahan individu bivalvia pada stasiun II.

Pada stasiun III terlihat bahwa presentasi yang paling tertinggi masih jenis Anadara gubernaculum sebesar $19.00 \mathrm{Ind} / \mathrm{m}^{2}$ kemudian Fragum unedo dan Atrina pectinata sebesar $1.00 \mathrm{Ind} / \mathrm{m}^{2}$ (Gambar 5).

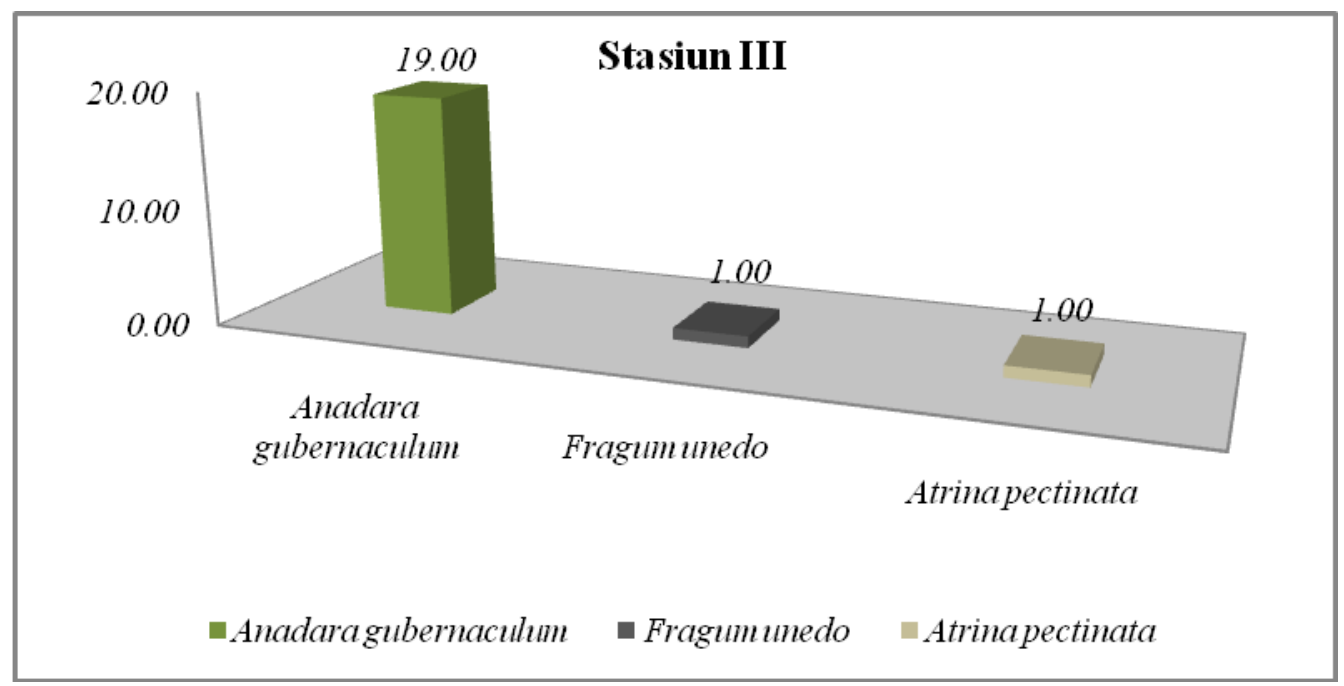

Gambar 5. Grafik kelimpahan individu bivalvia pada stasiun III.

Pada stasiun IV terlihat bahwa jumlah kelimpahan presentasi yang paling tertinggi Anadara gubernaculum sebesar $20.00 \mathrm{Ind} / \mathrm{m}^{2}$ dan yang menempati urutan ke dua yaitu 
dari jenis Ostrea lurida $5.00 \mathrm{Ind} / \mathrm{m}^{2}$ kemudian oleh Fragum unedo sebesar $1.00 \mathrm{Ind} / \mathrm{m}^{2}$ ( Gambar 6).

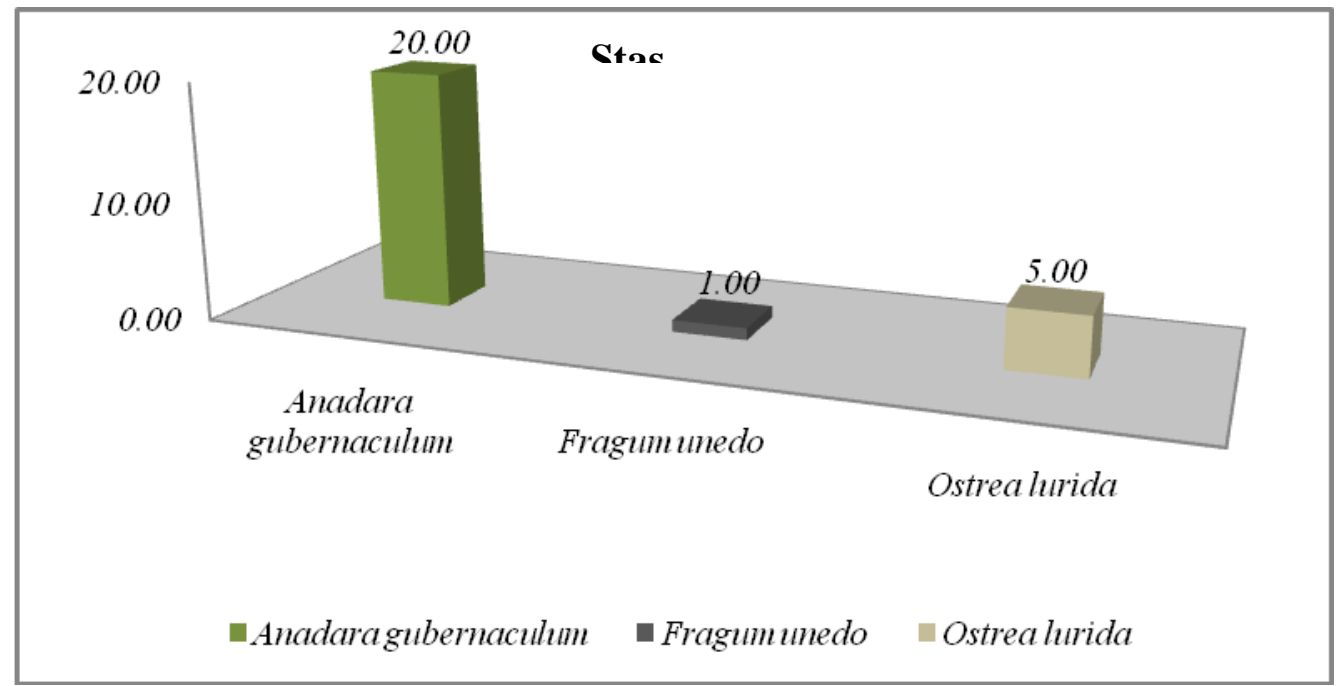

Gambar 6. Grafik kelimpahan individu bivalvia pada stasiun IV

Pada stasiun 1,2,3 dan 4 jumlah presentasi kelimpahan individu yang paling mendominasi di setiap stasiun yaitu jenis Anadara gubrnaculum dan yang ke dua yaitu dari jenis Fragum unedo sedangkan Kelimpahan yang paling terendah yaitu jenis Donax trunculus, Dosinia dilecta, Latona ceonata, Atrina pectinata dan ostrea lurida hal ini sependapat dengan, (Akhrianti et al, 2014). Sebagaimana yang dikemukakan Hasibuan dan Rusliadi (2009) dalam Susanti, et al (2013), bahwa bivalvia hidup di substrat berlumpur atau berpasir. Dengan demikian dapat disimpulkan bahwa tipe substrat lumpur yang tinggi dapat meningkatkan kelimpahan bivalvia karena tipe substrat lumpur sangat disukai oleh organisme bivalvia. Nybakken (1992) dalam Susanti, et al (2013), menambahkan bahwa perbedaan tekstur substrat dapat menyebabkan perbedaan jenis bivalvia yang hidup di substrat tersebut.

Tingginya kelimpahan bivalvia disebabkan kandungan bahan organik substrat yang tinggi dan jenis substrat yang mengandung lumpur. Hal ini sesuai dengan pendapat Dahuri (2004) dalam Siregar, et al (2013), yang menyatakan bahwa bivalvia merupakan biota yang banyak ditemukan pada substrat yang berlumpur. 


\section{Kelimpahan Relatif}

Berdasarkan hasil analisi kelimpahan relatif yang ditemukan diperairan Desa Juanga terlihat bervariasi pada semua stasiun penelitian. Pada stasiun I Anadara gubernaculum merupakan jenis yang memiliki kelimpahan tertinggi sebesar $47 \%$ selanjutnya Fragum unedo $26 \%$ sedangkan kelimpahan terendah yaitu jenis Latona cuenata hanya $3 \%$ (Gambar 7).

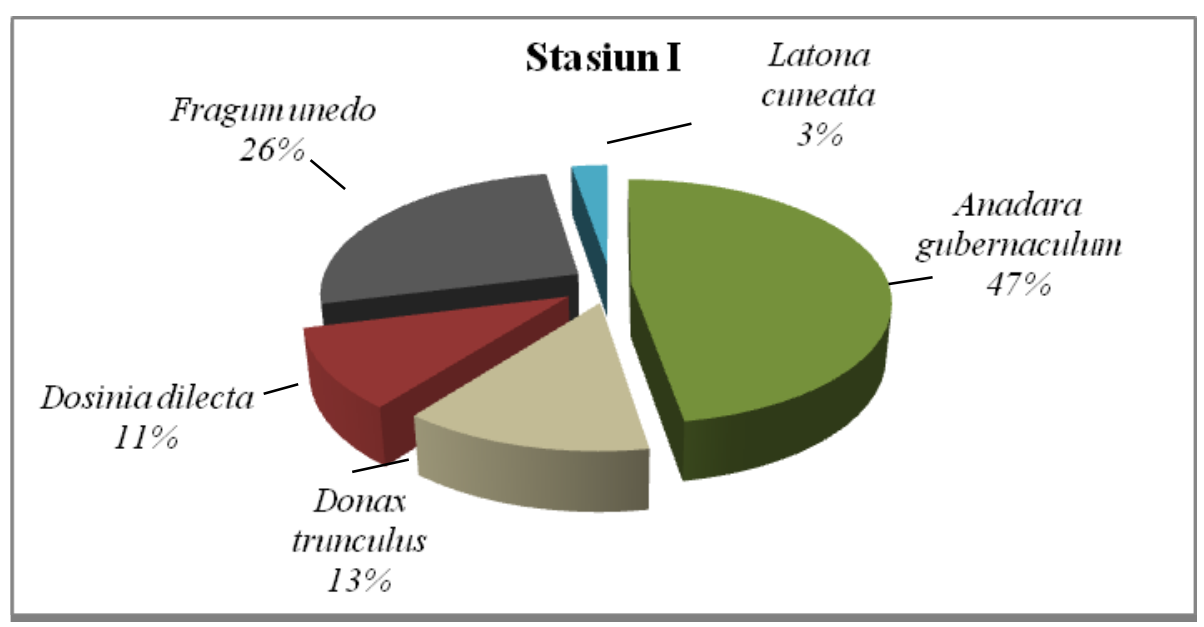

Gambar 7. Grafik kelimpahan relatif stasiun I

Pada Gambar 8 terlihat bahwa kelimpahan jenis bivalvia yang ditemukan pada stasiun II dengan persentasi tertinggi sebesar $96 \%$ masih dari jenis Anadara gubernaculum sedangkan terendah dari jenis Fragum unedo dengan nilai persentase sebesar $4 \%$

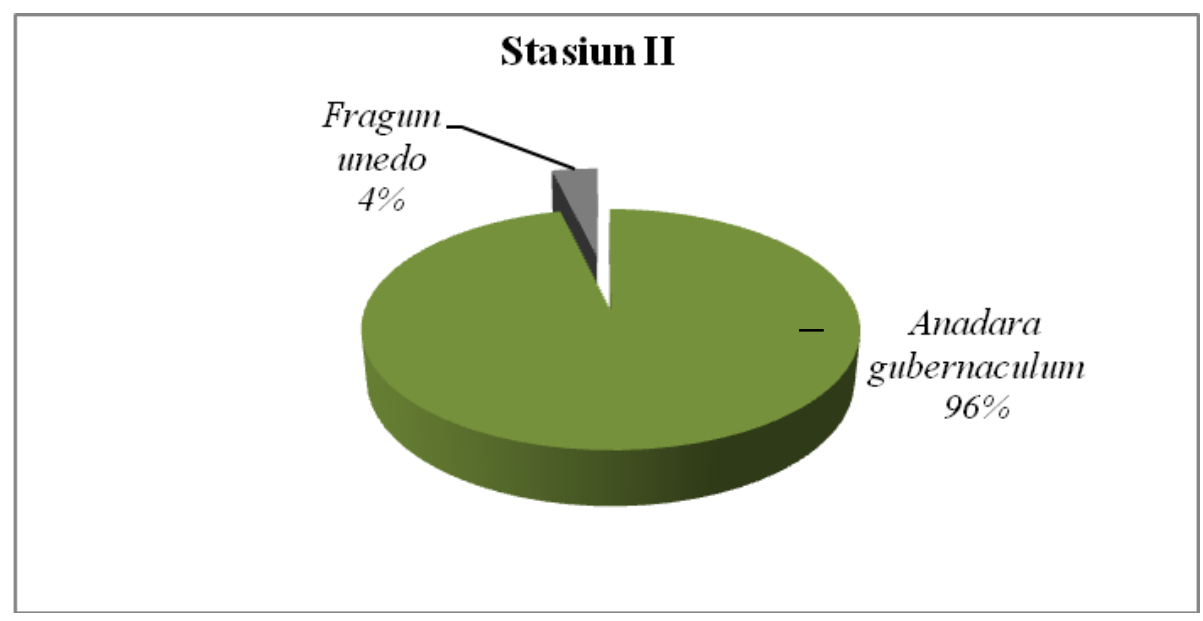

Gambar 8. Grafik kelimpahan relatif stasiun II 
Pada Gambar 9 terlihat bahwa kelimpahan jenis bivalvia yang di temukan pada stasiun III dengan nilai presentasi sebesar 90\% masih sama dengan jenis Anadara gubernaculum sedangkan jenis Antrina pectinata dengan presentasi sebesar 5\% begitu juga dengan jenis Fragum onedo dengan presentasi sebesar 5\%.

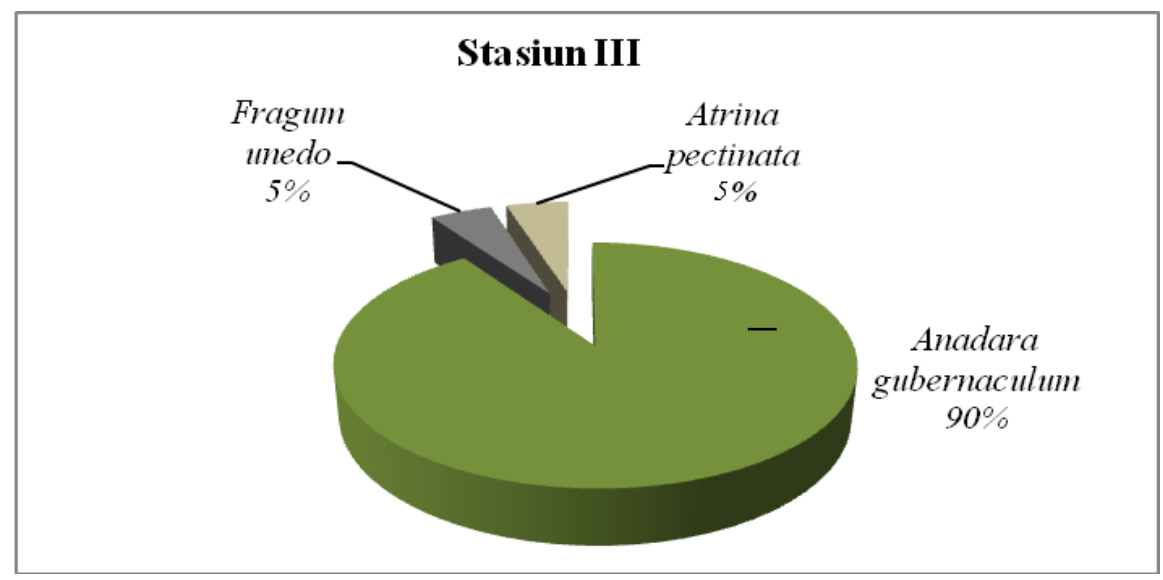

Gambar 9. Grafik kelimpahan relatif stasiun III

Pada Gambar 10 bahwa kelimpahan relatif jenis bivalvia yang paling tinggi presentasi sebesar 77\% masih dari jenis Anadara gubernaculum sedangkan jenis Fragum unedo $19 \%$ dan yang paling rendah itu jenis Ostrea lurida dengan presentasi sebesar 4\%.

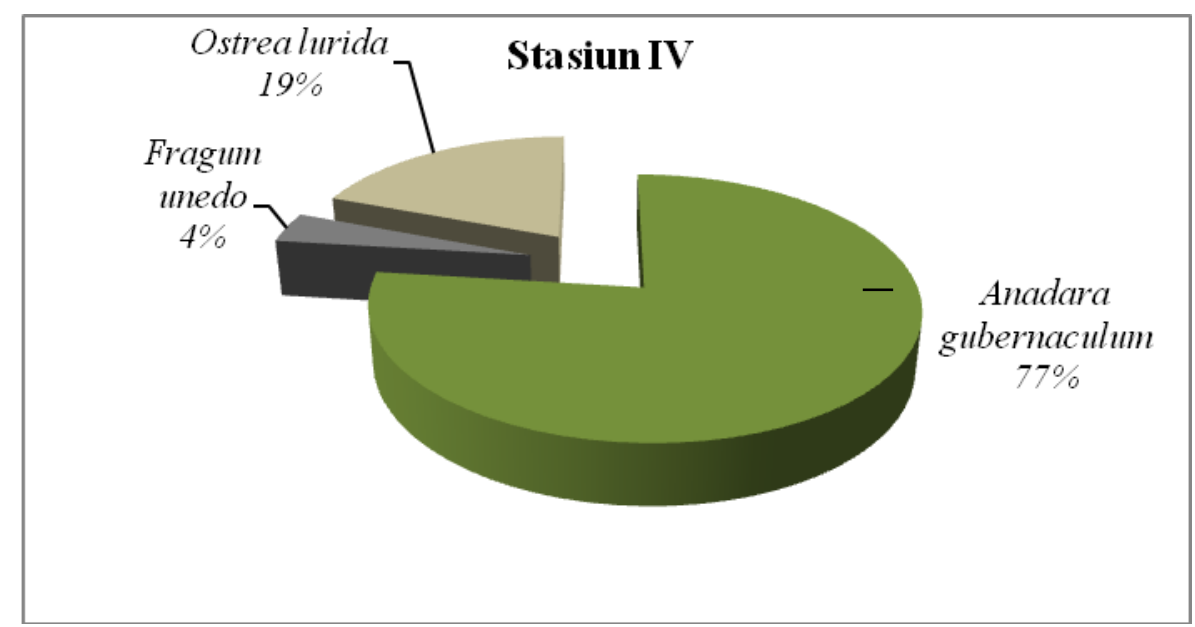

Gambar 10. Grafik kelimpahan relatif stasiun IV

Hasil analisis kelimpahan relatif jenis bivalvia pada stasiun 1-4 diatas, terlihat bahwa Anadara gubernicum merupakan jenis yang ditemukan disemua stasiun penelitian dan memilki nilai persentase tertinggi dibandingkan dengan jenis lainnya. Hal ini menandakan habitat yang ditempati sudah sesuai dengan kehidupannya, daya adaptasi 
terhadap perubahan lingkungan dan persaingan antara sesama jenis baik dari segi makanan maupun tempat, menyebabkan populasinya meningkat. Selain itu juga besar kemungkinan jenis ini juga terhindar kegiatan penangkapan dari masyarakat sekitarnya, karena karakternya merupakan organisme infauna (membenamkan diri dalam substrat). Menurut Arfiati (1986) dalam Lindawaty et al ( 2016) bahwa aspek ekologi yang dibutuhkan adalah substrat, salinitas, makanan, ruang serta hubungan dengan biota lain yang ada disekitarnya.

Jenis anadara memiliki adaptasi khusus yang memungkinkan dapat bertahan hidup pada daerah yang memperoleh tekanan fisik dan kimia seperti terjadi pada daerah intertidal. Organisme ini juga memiliki adaptasi untuk bertahan terhadap arus dan gelombang. Namun demikian jenis ini tidak memiliki kemampuan untuk berpindah tempat secara cepat (motil) (Setyono, 2006).

Keberadaan berbagai organisme bivalvia sangat bergantung pada ekosistem padang lamun sebagai habitatnya jika lamunnya dalam kondisi yang baik maka semakin banyak organisme yang menepati habitat tersebut. Hal ini sejalan dengan pendapat Yuliana dan Asriyana (2012) bahwa tingginya produktivitas primer di ekosistem padang lamun, bisa mencapai $5000 \mathrm{gC} / \mathrm{m} 2 /$ tahun, memicu produktivitas sekunder yang tinggi yang berarti komunitas makhluk hidup yang ada didalamnya sangat beranekaragam dan tersedia dalam jumlah yang melimpah.

Jenis Anadara guberculum merupakan bivalvia yang paling banyak ditemukan disemua stasiun penelitian, kebanyakan jenis ini ditemukan membenamkan diri didalam substrat dengan cara menggali liang didalam pasir. Hal ini terlihat pada saat pengambilan sampel bivalvia dengan menggunakan pipa paralon (pipa core) banyak ditemukan jenis Anadara guberculum dibandingkan jenis lainnya yang kebanyakan berada dipermukaan substrat. Sejalan dengan itu Lindawaty et al (2016) menyatakan bahwa kerang Anadara bersifat infauna yang hidupnya dengan cara membenamkan diri kedalam substrat. Jenis lain seperti Fragum onedo merupakan jenis yang banyak diambil oleh masyarakat sekitar untuk dikonsumsi, karena hidupnya dipermukaan substrat dan tergolong hewan epifauna sehingga muda ditangkap. Sementara jenis Anadara guberculum ditemukan dalam jumlah yang banyak kemungkinan karena jenis ini tidak dapat dijangkau karena sifat hidupnya yang membenamkan diri dalam substrat. 
Selain itu, habitat juga sangat berpengaruh pada jumlah jenis dan penyebaran individu dari jenis ini. Spesies anadara termasuk ekonomis penting dan umumnya mendiam substrat yang lunak, kerang Anadara banyak ditemukan pada substrat lumpur berpasir (Lindawaty et al 2016). Hasil pengamatan substrat diperairan Desa Juanga secara umum didominasi oleh substrat pasir berlumpur (Tabel 1) yang sesuai dengan pertumbuhan dan perkembangan jenis Anadara guberculum.

\section{Parameter Lingkungan}

Hasil pengukuran parameter lingkungan dilokasi penelitian yang mempengaruhi perkembangan jenis-jenis bivalvia seperti salinitas, suhu dan $\mathrm{pH}$, dari empat stasiun pengamatan tidak ada perbedaan yang signifikan, nilai parameter yang diukur berupa salinitas di 4 stasiun sama yakni $33-35 \%$, suhu $29^{\circ} \mathrm{C}$ dan $\mathrm{pH}$ berada pada kisaran 8 - 8 (selengkapnya dapat di lihat pada Tabel 2)

Tabel 2. Hasil Pengukuran Parameter Kualitas Perairan

\begin{tabular}{|c|c|c|c|c|c|}
\hline \multirow{2}{*}{ No } & \multirow{2}{*}{ Parameter } & \multicolumn{3}{|c|}{ Stasiun } & \multirow[b]{2}{*}{ IV } \\
\hline & & I & II & III & \\
\hline 1 & Suhu $\left({ }^{\circ} \mathrm{C}\right)$ & 29 & 29 & 29 & 29 \\
\hline 2 & Salinitas (\%o) & 35 & 35 & 33 & 33 \\
\hline 4 & $\mathrm{pH}$ & 8 & 8 & 8 & 8 \\
\hline 5 & Substrat & $\begin{array}{c}\text { Pasir- } \\
\text { berlumpur }\end{array}$ & $\begin{array}{c}\text { Pasir- } \\
\text { berlumpur }\end{array}$ & Pasir-berlumpur & Pasir-berbatu \\
\hline
\end{tabular}

Dari data tersebut dapat dijelaskan bahwa parameter lingkungan yang berada di lokasi penelitian tidak berbeda antara stasiun dan masih pada batas optimum untuk perkembangan dan pertumbuhan berbagai makhluk hidup terutama jenis-jenis bivalvia penghuni lamun.

Menurut Wijayanti (2007) bahwa suhu dapat membatasi sebaran hewan makrozoobenthos secara geografik dan suhu yang baik untuk pertumbuhan hewan makrozoobenthos berkisar antara $25-31{ }^{\circ} \mathrm{C}$ Berdasarkan kondisi tersebut, kondisi suhu masih layak untuk kehidupan makrofauna karena masih sesuai pada kisaran optimal yang ditentukan. 
Wijayanti (2007) menyatakan bahwa kisaran salinitas yang optimal bagi kehidupan organisme bentos salah satunya dari kelas bivalvia pada ekosistem perairan adalah pada kisaran 25 - 40\%o . Mengacu dari kedua pendapat tersebut, salinitas masih baik bagi kehidupan makrofauna Bivalvia. sedangkan $\mathrm{pH}$ yang mendukung kehidupan moluska berkisar antara 5,7 - 8,4, dan untuk molluska hidup pada batas kisaran pH 5,8 - 8,3. Dengan demikian kondisi $\mathrm{pH}$ masih dikatakan layak untuk kehidupan makrofauna (Wijayanti 2007).

Tipe substrat yang ada dilokasi penilitian terdiri dari pasir berlumpur. Komposisi pasir lebih besar yaitu 90\% dibanding dengan komposisi Gravel (kerikil/batu). Nilai oksigen akan lebih besar pada substrat pasir dibandingkan yang berlumpur. Menurut Lindawaty et al, (2016), jenis substrat sangat mempengaruhi penyebaran untuk biota akuatik, substrat, pasir dan lumpur cenderung memudahkan biota untuk bergerak ketempat yang lain.

\section{KESIMPULAN DAN SARAN}

Berdasarkan analisis hasil penelitian yang telah dilakukan, maka dapat disimpulkan sebagai berikut :

1 Terdapat 7 spesies Bivalvia yang tersebar di empat stasiun penelitian yakni jenis Anadara gubernculum, Donax trunculus, Dosinia dilecta, Frogum unedo, Latona cuenata, Atrina pectinata dan Ostrea lurida dengan total individu adalah 112 individu.

2 Komposisi spesies dari Bivalvia tertinggi ketegori (absolut) yaitu Anadara gubernculum dengan persentase komposisi sebesar 0,74, sedangkan untuk spesies lain secara keseluruhan memiliki komposisi kategori (rendah) dengan nilai dibawah 0,23.

3 Kelimpahan individu dan kelimpahan relatif disemua stasiun yang memiliki nilai tertinggi yaitu jenis Anadara gubernculum. 


\section{UCAPAN TERIMA KASIH}

Ucapan terima kasih disampaikan kepada Laboratorium Fakultas Perikanan dan Ilmu Kelautan (FPIK) Universitas Pasifik Morotai, yang telah mendanai dan bersedia memberikan kesempatan penelitian.

\section{DAFTAR PUSTAKA}

Akhrianti, Irma., Dietrich, G Bengen., Isdrajad, Setyobudi. 2014. Distribusi Spasial dan Preferensi Habitat Bivalvia di Pesisir Perairan Kecamatan Simpang Pesak Kabupaten Belitung Timur. Jurnal Ilmu dan Teknologi Kelautan Tropis. Vol. 6. No. 1.

Arfiati, D. 1986. Survei habitat dan sebaran populasi kerang (anadara sp. )di Pantai Desa Pesisir, Probolinggo, Jawa Timur (laporanpenelitian).Universitas Brawijaya. Malang.

Brower, JE., and Zar., JH. 1998. Field and Labolatory Methods for General Ecology. The Ncgraw-Hill Companies. USA

Cox, GW. 1967. Laboratory manual of General Ecology: $4^{\text {th }}$ Edition. Wm. C. Brown Company Publishers. USA, pp: 41-46.

Effendy, I.J. 1993. Komposisi Jenis dan Kelimpahan Makrozoobentos pada Daerah Pasang Pantai Bervegetasi Mangrove di Sekitar Teluk Mandar Desa Miring Kecamatan Pole Wali Kabupaten Polmas. Fakultas Peternakan Universitas Hasanuddin. Ujung Pandang.

English SWC, Baker V. 1997. Survey manual for tropical marine resources. Australian Institute Of Marine Science. Townsville. Germany.

Hasibuan, N., dan Rusliadi. 2009. Buku Ajar Avertebrata Air. Pusat Pengembangan Pendidikan. Universitas Riau,Pekanbaru. 188 hal.

Hermala, A., Zulfikar dan T, S. I. Raza. 2015. Hubungan Kerapatan Lamundengan Kelimpahan Bivalvia di Pesisir Pantai Dolpin Desa Teluk Bakau Kabupaten Bintan. Universitas Maritim Raja Ali Hajli, Kepulauan Riau.

Lindawaty, Dewiyanti, I., Karina, S. 2016. Distribusi dan Kepadatan Kerang Darah (Anadara sp) Berdasarkan Tekstur Substrat di Perairan Ulee Lheue Banda Aceh. Jurnal Ilmiah Mahasiswa Kelautan dan Perikanan Unsyiah. 1(1): 114-123.

Nybakken, J.W. 1992. Biologi Laut: Suatu Pendekatan Ekologis. Gramedia, jakarta (penerjemah H. Muhammad Eidman). 
Patrick, L.C., dan Arneson C 1995. TropicalPasificInvertebratesPublished by:Coral Reef Press 270 North Canon Drive, Suite 1524 Beverly Hills, California 90210 U.S.A. ISBN 0-9645625-0-2.

Putri, R. E. 2005. Analisa Populasi dan Habitat Sebaran Ukuran dan Kematangan Gonand Kerang Lokan (Batisa violancae) di Muara Sungai Anai Padang, Sumatera Barat. Tesis Sekolah Pasca Sarjana Institut Pertanian Bogor.

Romimohtarto, K., dan S. Juwana. 2001. Biologi Laut. Ilmu Pengetahuan Tentang Biota Laut. Penerbit Djambatan. Jakarta.

Septiana, Indry Nella. 2017. Keanekaragaman Bivalvia dan Gastropoda Di Pantai Pasir Putih Kalianda Lampung Selatan.Skripsi Biologi : Fakultas Tarbiyah dan Keguruan, Universitas Islam Negeri Raden Intan Lampung.

Setiawan F. 2010. Panduan Lapangan Identifikasi Ikan Karang Dan Invertebrata Laut. Sulawesi Utara. Manado. (ID): Wildlife Concervation Society.

Setyono, D. E. D. 2006. Karakteristik Biologi dan Produk Kekerangan Laut. Jurnal Oseana 31, (1) : 1-7.

Siregar, RA., Yunasfi dan Surianti A. 2013. Komunitas Bivalvia dan Gastropoda di Pantai Cermin Sumatra Utara. Sumatra Utara: Universitas Sumatra Utara.

Susanti, Evi., dan Bintari, Yonirina. 2013. Karakterisasi ekstrak kasar sistem selulase potensial dari bacillus subtilis. Prosidin Seminar Nasional Kimia UGM.

Wahab I, Madduppa H, Kawaroe M. 2018. Perbandingan Kelimpahan Makrozoobentos di Ekosistem Lamun Pada Saat Bulan Purnama dan Perbani di Pulau Panggang Kepulauan Seribu Jakarta. Jurnal Ilmu dan Teknologi Kelautan Tropis. 10(1): 217229. DOI: http://dx.doi. org/10.29244/jitkt.v10i1.18974.

Wahab I., Hawis, Madduppa., Mujizat, Kawaroe., Nurafni. 2019. Analisis Kepadatan Makrozoobentos Pada Fase Bulan Berbeda Di Lamun, Pulau Panggang, Kepulauan Seribu Jakarta. Jurnal Teknologi Perikanan dan Kelautan, Vol. 10 No. 1 Mei 2019: 93-107.

Wahyudin, Y., T, Kususmanto., L, Adrianto dan Y., Wardianto. 2016. Jasa Ekosistem Lamun Bagi Kesejahteraan Manusia. Vol. 12(3). ISSN: 1858-3873.

Wijayanti, H. 2007. Kualitas Perairan di Pantai Kota Bandar Lampung Berdasarkan Komunitas Hewan Makrobenthos. [Tesis].Universitas Diponegoro. Semarang.

Yuliana dan Asriyana. 2012. Produktivitas Perairan. Penerbit PT Bumi Aksara. Jakarata. Hal 278. 
Yusran. 2014. Identifikasi Keanekaragaman Jenis Kerang (bivalvia) Daerah Pasang Surut Di Perairan Pantai Pulau Gosong Sangkalan Aceh Barat Daya. Skripsi Program Studi Perikanan. 